\title{
Information Disclosure Ranking, Industry Production Market Competition, and Mispricing: An Empirical Analysis
}

\author{
Bing Wang ${ }^{1}$, Si Xu ${ }^{2, *}$, Kung-Cheng Ho ${ }^{3 \oplus}$, I-Ming Jiang ${ }^{4}$ and Hung-Yi Huang ${ }^{5}$ \\ 1 School of Accounting, Fujian Jiangxia University, Fuzhou 350108, China; wangbing@fjjxu.edu.cn \\ School of Economics \& Management, South China Normal University, Guangzhou 510006, China \\ 3 School of Finance, Collaborative Innovation Center of Industrial Upgrading and Regional Finance (Hubei), \\ Zhongnan University of Economics and Law, Wuhan 430073, China; z0004531@zuel.edu.cn \\ 4 Faculty of Digital Finance, College of Management, Yuan Ze University, Taoyuan 32003, Taiwan; \\ jiangfinance@saturn.yzu.edu.tw \\ 5 Department of Business Administration, Soochow University, Taipei 10048, Taiwan; hy.huang@scu.edu.tw \\ * Correspondence: xusi@m.scnu.edu.cn
}

Received: 13 December 2018; Accepted: 30 December 2018; Published: 7 January 2019

\begin{abstract}
Improving the transparency of corporate information disclosure is a key principle of corporate governance in Taiwan. This study uses the information disclosure assessment system established by the information disclosure and transparency ranking system to explore whether information transparency can reduce the degree of mispricing. The study uses the data of 10,686 listed companies in Taiwan for the period from 2005 to 2014. We find that a higher information disclosure ranking (IDR) of rated companies corresponds to a more substantial reduction in the degree of mispricing. Moreover, we discover that product market competition affects mispricing in that smaller degrees of mispricing reflect greater exclusivity; this suggests that lower industry transaction and competition costs lead to less substantial mispricing. Finally, we observe that the effect of information disclosure score on the degree of mispricing is lower in more exclusive industries. Furthermore, a regression process using instrumental variables reveals that IDRs have the significant effect of reducing the degree of mispricing.
\end{abstract}

Keywords: information disclosure ranking; industry production market competition; mispricing; Taiwan stock market

JEL Classification: G18; G30; G34

\section{Introduction}

Financial fraud, such as that committed by Tyco, Enron, and WorldCom, has become prevalent. Some internal managers or shareholders take advantage of their own business operations out of self-interest, leaving investors with insufficient information in a relatively weak position. Detecting fraud that causes loss to investors and corporate decline is difficult [1-3].

Therefore, in addition to a greater amount of attention paid by scholars and people practicing business to the matter of information disclosure, financial supervision agencies in various countries have developed guidelines for measuring transparency when encouraging enterprises to improve information disclosure. In 2003, the Taiwan Stock Exchange Corporation (TSEC) entrusted the Securities and Futures Institute (SFI) with the task of improving the information disclosure system to ensure a reduction in information asymmetry between insiders and outsiders on all companies listed in the TSEC. The purpose of this information disclosure system is to plan and design evaluation 
indicators that meet the needs of the information disclosure and transparency ranking system (IDTRS). The investment publication is expected to be capable of easily determining the degree of corporate information asymmetry by publishing evaluation grades for listed companies annually.

Differences in information disclosure often imply that various agency problems $[4,5]$, stock liquidity [6,7], corporate capital costs [8,9], and earnings quality [10] may influence enterprise value. Moreover, the evaluation level naturally becomes an auxiliary reference for investor decisions.

The relationship between information disclosure quality and corporate value is inextricable. Improving the integrity of information disclosure can improve the quality of information disclosure, reduce corporate capital costs, and increase shareholder wealth [11]. This effectively repairs damage caused by information asymmetry between shareholders and operators [12,13]; moreover, it can mitigate the effect of excessive executive compensation on company value and enhance corporate value [14]. Merton [15] indicated that the complete disclosure of information helps investors identify with the company and attract new investors, which can reduce the cost of capital and increase the value of the company. Diamond and Verrecchia [7] also discovered that incensement in response to information disclosure can reduce information asymmetry and transaction costs, improve liquidity, and reduce corporate capital costs [16-18]. Klapper and Love [19] explored 14 emerging markets and discovered that more effective corporate governance corresponds to favorable operational performance and corporate value. Bai et al. [20], Black et al. [21], and Braga-Alves and Shastri [22] have examined corporate governance in China, the Soviet Union, Mexico, and Brazil, respectively, and its relationship with company value, and they have reached the same conclusion as the aforementioned study. Ho et al. [23] applied the data of listed companies in Taiwan for the period from 2005 to 2013 to demonstrate that product market competition is negatively correlated with corporate value and that when product market competition is weak, information disclosure is more conducive to company value.

According to the aforementioned research, information disclosure can effectively reduce information asymmetry, reduce company costs, and enhance company value. However, because information disclosure also has external costs, more disclosure is not always better. Excessive disclosure of information may provide competitors with a better understanding of the company's strategy, profitability, and innovation level as well as weaken competitive advantages [24]. Bloomfield and Fischer [25] explored the effects of information disclosure on capital costs, reporting that corporate capital costs increase when firms believe that investors respond to noncritical disclosures.

Product market competition is often considered an external mechanism that affects information disclosure [23]. Information disclosure is endogenous but also influenced by the market competition environment. One view holds that industries with low levels of competition tend to have excess returns and therefore low levels of information disclosure. Information disclosure can also help sellers to distinguish themselves from competitors. However, the fierce competition in the product market is not always beneficial. Other studies have conducted a relatively comprehensive exploration of market competition level by measuring the degree of market product differentiation; they have discovered that higher levels of competition correspond to lower likelihood of high-quality information disclosure. Research has also demonstrated that if the cost of disclosure is high, companies will disclose higher-quality information. When the market itself is more competitive and disclosure cost is higher, competitors will tend to disclose higher-quality information to mitigate high costs. When the degree of competition in the market is not high, competition will always lead to the disclosure of low-quality information regardless of the level of cost.

The degree of mispricing affects the choice of financing method. Baker et al. [26] indicated that when companies rely heavily on equity financing, the effect of mispricing on equity financing is more obvious. However, even if external financing is not required, mispricing may directly affect company investments. The degree of mispricing is affected by many factors [27]. Sloan [28] proposed that investors do not understand that inherent future earnings information is the primary cause of mispricing. Moreover, because the quality of public information remains at the same level, an increased amount of information does not necessarily correspond to a reasonable equity valuation. Compliance 
with regulations improves company information environments, reduces mispricing, and increases stock market efficiency. Furthermore, policymakers should consider the quality of information provided when attempting to increase capital market efficiency by forcing more disclosures.

Emerging markets possess the characteristics of rapid economic development and remarkable market potential. However, their market economic system remains in a stage of gradual improvement, their external supervision mechanism is not perfect, their information disclosure mechanism is incomplete, and their internal control system of listed companies is inadequate. Investors are more likely to be in an unfavorable position when investing with limited information acquisition and professional knowledge. Therefore, improving the level of investor protection and exploring the relationship between information disclosure and degree of corporate value is necessary to enable investors to more accurately judge investment value. Some scholars have turned their attention away from mature markets to investigate whether emerging markets are subject to the same phenomenon [29].

Investor relations indicators provided by the Association for Investment Management and Research (AIMR) and the Center for International Financial Analysis and Research (CIFAR) can be used as a measure of information disclosure, in addition to other variables used as information disclosure agents [30,31]. However, the AIMR score is not available after 1996, and the CIFAR indicator system does not include Taiwan. We use the SFI information disclosure ranking (IDR) as a measure of information disclosure quality and expand the scope of application of SFI IDRs. By contrast, SFI forms a research team composed of experts from independent parties-consisting of the accounting and finance profession, academic researchers, in-house research staff, and IT personnel-using 114 measures to evaluate the information quality of all listed firms, except for some firms with inadequate data or under regulatory investigation. Therefore, the disclosure scores are based on the same set of information criteria and are not skewed to large firms and variation in accounting standards. The research results are highly relevant to Taiwan's actual situation and possess certain theoretical value.

We show our main results and contributions. First, using a relatively large sample, this study provides further support for the effectiveness of the information disclosure ranking in reducing information asymmetry between enterprises and investors and reflects the degree of mispricing in emerging markets. Our results show that information disclosure ranking, industry production market competition and their interaction did influence the mispricing of Taiwanese firms between 2005 and 2014. Second, we find unique data that shows the SFI's measurements for information disclosure ranking are negatively associated with mispricing. It suggests that higher levels of information disclosure rankings (transparency) reduce agency problems, thus leading to lower mispricing. Third, we find that the benefits of increased information disclosure rankings levels are significant only for firms that face strong competition in the product market, compared to other firms in less competitive industries. Finally, we solve the endogeneity problem to improve the degree of mispricing, information disclosure may improve the information disclosure score as a result of decreased mispricing. In summary, the primary purpose of the evaluation system is to provide investors with a convenient pipeline for knowing the level of information disclosure of a company, thereby helping investors to make more informed investment decisions. However, the implementation of the system also indirectly forces enterprises to improve the quality of their information disclosure. The information disclosure evaluation system reduces information asymmetry between enterprises and investors and reflects the degree of mispricing. We argue that information disclosure rankings could facilitate managers' forward thinking, and firms with better information disclosure rankings or corporate social responsibility not only aim to reduce short-term mispricing but also focus on long-term sustainable development [32-39]. Moreover, information disclosure rankings firms are found to be more ethical [23,40], and managers are encouraged to undertake actions that boost long-term firm value, thus resulting in less mispricing.

This paper is structured as follows: the first section introduces the research background and literature review, the second section presents the hypothesis development, and the third section explains the sample and the definition of variables required in this study. The fourth section provides 
an analysis of the empirical results, and the final section presents conclusions drawn on the basis of the empirical findings of this study.

\section{Hypothesis Development}

\subsection{Information Disclosure and Mispricing}

Information disclosure is inextricably linked to mispricing. According to Hail [41], the effect of information pre-disclosure is favorable in developing markets because of relatively relaxed regulations and the lack of mandatory public rankings. Conversely, the trading market has higher levels of disclosure and a smaller discrepancy between real values and market expectations. Drake et al. [42] argued that because the quality of disclosed information improves the ability of investors to more accurately assess the sustainability of accruals and cash flow and their effect on future stocks, companies with higher-quality information disclosure experience less mispricing. Jiao [43] suggested that the amount of information disclosure is positively related to return on stocks, which may be because increased information transparency can correct mispricing. Kobayashi et al. [44] indicated that disclosure of patent information can significantly reduce risk and produce a relatively low standard deviation of $9.25 \%$; in other words, disclosure of patent information helps to reduce mispricing. However, some scholars who have conducted research using news reports have reported contradictory results $[40,45,46]$. It demonstrate that inaccurate news reports make investors more critical and less likely to invest, resulting in mispricing and deviations in company value.

Through the implementation of the information disclosure evaluation system, we explore whether the increase in quality of information disclosure can effectively reduce information asymmetry between enterprises and investors and thus reduce mispricing. We present the following hypothesis:

Hypothesis 1 (H1). Information disclosure rankings reduce mispricing.

\subsection{Effect of IDR on Mispricing under Different Levels of Industry Product Market Competition}

Regarding supplementation and substitution of information disclosure, Bens [47] measured the amount of information that US companies voluntarily disclosed during 1990-1993 and discovered that significantly more information was disclosed when the SEC increased its supervision of restructuring companies at the end of 1993. He found that the positive relationship between amount of information disclosure and shareholder supervision indicates that supervision supplements disclosure.

Another study discerned a different relationship between information disclosure and product market competition. Healy and Palepu [48] suggested that voluntary company disclosure of information such as long-term strategic and nonfinancial indicators may increase the credibility of the financial reports of managers for competitive products. Increasing market disclosure may negatively affect the competitive position of companies. Similarly, Elliott and Jacobson [24] demonstrated that information disclosure can benefit public relations, such as by gaining the trust of investors and creditors. However, because potential competitors can acquire knowledge concerning marketing strategies, segment sales, production cost figures, technology, and management innovations from proprietary information, disclosure can increase competition and undermine the ability of a company to generate future cash flows. Giroud et al. [49] discovered that corporate merger laws weaken corporate governance by reducing the threat of hostile takeovers and prompting insufficient management. Giroud and Mueller [50] reported that in a noncompetitive industry, companies with weak governance are more likely to be investment targets for radical hedge funds, suggesting that investors actively mitigate inefficiencies. Ho et al. [23] investigated whether information disclosure is related to company value in markets with different levels of competition, revealing that information disclosure and product market competition levels affect company value. Consistent with the concept of competition to reduce management slack, companies in noncompetitive industries experienced a significant decline 
in business performance after the law was enacted, whereas companies in competitive industries were not significantly affected. We present the following hypothesis:

Hypothesis 2 (H2). The negative relationship between information disclosure and mispricing is stronger for firms in competitive industries.

\section{Research Design}

\subsection{Sample Selection}

Since 2005, the SFI has implemented a public IDTRS for listed companies, thereby determining the information transparency level of companies in the Taiwan stock market. This is based on the discussion of whether the publication of information transparency level forces enterprises to commit to the improvement of information disclosure. After the implementation of the evaluation system, we select the annual data of 10,686 SFI companies for the period from 2005 to 2014 as the research object. The final sample is selected on the basis of the following conditions, as determined by evidence: (1) To ensure data consistency, we omit annual data of enterprises that had not used the calendar system. (2) Furthermore, to estimate the degree of mispricing, we exclude industries with fewer than five sample counts for any year during the sample period. The sample variables used in this study are obtained from the CSMAR and Taiwan Economic Journal.

\subsection{Variable Description}

\subsubsection{IDR Variable}

IDRs and information transparency are major concerns in corporate governance. Foreign information disclosure level is assessed using the indices of Standard \& Poor and Credit Lyonnais Securities regarding content concerning ownership, inverter, financial transparency, information disclosure, and board of director structure. The corporate governance ranking system has seven principles: management discipline, transparency, independence, accountability, responsibility, fairness, and social responsibility. Until 2014, the evaluation system for the ninth IDRs comprised scores from $\mathrm{A}++$ to $\mathrm{C}-$ with seven ranking indices. To assess the level of corporate transparency, information ratings identified 114 indicators as evaluation criteria, which can be further grouped into five sub-categories: (1) compliance with the mandatory information disclosures; (2) timeliness of information reporting; (3) disclosure of financial forecast; (4) disclosure of annual report; and (5) disclosure of corporate website. Each disclosure indicator represents a "yes" or "no" question. One point is given to the question with a "yes" answer and zero otherwise. This study discusses information transparency by categorizing $\mathrm{A}++$ to $\mathrm{C}-$ scores from 7 to 1 . The 114 questions used to compile the IDR scores for each sample firm are presented in Pan et al. [46].

\subsubsection{Industry Product Market Competition}

The primary measure of product market competition used in this study is the HerfindahlHirschman Index (HHI). The HHI is computed as the sum of squared market shares [50-52]:

$$
\mathrm{HHI}_{\mathrm{jt}}=\sum_{i=1}^{N_{j}} S_{i j t}^{2}
$$

where $S_{i j t}^{2}$ is the market share of firm $i$ in industry $j$ in year $t$. A higher HHI indicates higher industry exclusivity, and a lower $\mathrm{HHI}$ reflects a greater likelihood of the industry being a competitive industry. 


\subsubsection{Mispricing}

First, we use Equation (2) provided by Rhodes-Kropf et al. [53] and Chu et al. [40] to predict mispricing:

$$
\ln \left(\mathrm{MV}_{i j t}\right)=\alpha+\beta_{1} \ln \left(\mathrm{BE}_{i j t}\right)+\beta_{2} \ln \left(\mathrm{NI}_{i j t}^{+}\right)+\beta_{3} \mathrm{I}_{<0} \ln (\mathrm{NI})_{i j t}^{+}+\beta_{4} \mathrm{LEV}_{i j t}+\varepsilon_{i j t}
$$

where $\ln (\mathrm{MV})$ is the natural logarithm of market capitalization, $\ln (\mathrm{BE})$ is the natural logarithm of book value of equity, and $\mathrm{NI}$ is the absolute value of net income. $I_{<0}$ is a dummy variable that has a value of 1 when the net income is negative and 0 otherwise. LEV is the leverage ratio, calculated as the debt of firm $i$ divided by total assets.

Next, we use Equation (3) to compare corporate predicted and real value and estimate mispricing:

$$
\text { Mispricing }_{i t}=\ln \left[\text { Real value }_{i t} / \text { Predict value }_{i t}\right]
$$

where real value is the market value of equity plus book value of debt and predicted value is the estimated market capitalization of predicted value obtained from Equation (2).

With reference to Berger and Ofek [54] and Chu et al. [40], we predict value by multiplying sales revenue by the median market value for a company in the industry during the sample year and dividing this product by the median sales revenue for the industry. We define mispricing as the value of the sample real market value divided by the predicted market value. A higher difference in value indicates greater mispricing.

\subsubsection{Control Variables}

We follow Pan et al. [46] to consider firm characteristics and agency-based proxies [40], including the natural logarithm of market capitalization (SIZE), ratio of debt to book value of assets (LEV), total number of annual trading days (Trading), institutional ownership (Inshd), number of analysts providing earnings forecasts (Analyst), illiquidity ratio (Liquidity), shareholding of directors and supervisors (SDS), shareholding of the largest shareholder (SLS), voting rights (TFV), and listed company (TSE). All variables are defined in Table 1.

\subsection{Methodology}

To assess the influence of IDR on mispricing, we use Equation (4) as follows:

$$
\begin{aligned}
& \text { Mispricing }_{i t}=\beta_{0}+\beta_{1} \mathrm{IDR}_{i t}+\beta_{2} \mathrm{SIZE}_{i t}+\beta_{3} \mathrm{LEV}_{i t}+\beta_{4} \ln (\text { Trading })_{i t}+\beta_{5} \ln (\mathrm{Inshd})_{i t} \\
& +\beta_{6} \ln \left(\text { Liquidity }_{i t}+\beta_{7} \mathrm{SDS}_{i t}+\beta_{8} \mathrm{SLS}_{i t}+\beta_{9} \mathrm{TSV}_{i t}+\right.\text { Time FE } \\
& + \text { Industry FE }+\varepsilon_{i t}
\end{aligned}
$$

where Mispricing is derived using the two estimation methods proposed by Berger and Ofek [54] and Rhodes-Kropf et al. [53] discussed in Section 3.2.3. Time FE is year fixed effects, and industry FE is industry fixed effects. These variables are defined in Table 1.

To provide further evidence, this study examines the effect of IDR on mispricing in industries with different levels of product market competition. According to the procedure developed by Giroud and Mueller [50], we use Equation (5) to perform estimates in this study:

$$
\begin{aligned}
& \text { Mispricing }_{i t}=\gamma_{0}+\gamma_{1}\left(\mathrm{IDR}_{i t} * \mathrm{HHI}_{i t}\right)+\gamma_{2} X_{i t}+\gamma_{3} \mathrm{SIZE}_{i t}+\gamma_{4} \mathrm{LEV}_{i t} \\
& +\gamma_{5} \ln (\text { Trading })_{i t}+\gamma_{6} \ln (\text { Inshd })_{i t} \\
& +\gamma_{7} \ln (\text { Liquidity })_{i t}+\gamma_{8} \mathrm{SDS}_{i t}+\gamma_{9} S L S_{i t}+\gamma_{10} \mathrm{TSV}_{i t}+\text { Time FE } \\
& + \text { Industry FE }+\varepsilon_{i t}
\end{aligned}
$$


where $\mathrm{HHI}$ is a $(3 \times 1)$ vector of $\mathrm{HHI}$ dummies for high, medium, and low levels of industry product market competition. $X$ denotes the control variables, which are HHI dummies for medium and low levels of industry product market competition.

Table 1. Definition.

\begin{tabular}{|c|c|c|c|c|}
\hline \multicolumn{5}{|l|}{ Panel A: Variable definition } \\
\hline Variable & \multicolumn{4}{|c|}{ Explanation } \\
\hline Mispricing1 & \multicolumn{4}{|c|}{ We use Rhodes-Kropf et al. [53] and Chu et al. [40] method to predict mispricing. } \\
\hline Mispricing2 & \multicolumn{4}{|c|}{$\begin{array}{l}\text { Market value of equity plus book value of debt to imputed value of total capital to sales } \\
\text { for the median single-segment firm in industry and year }[40,54] \text {. }\end{array}$} \\
\hline & \multicolumn{4}{|c|}{ Industry Characteristics } \\
\hline HHI & \multicolumn{4}{|c|}{$\begin{array}{l}\text { Set the product market competition index as the dummy variable and use SALES as the } \\
\text { measurement variable. If the HHI index is higher than the average } \mathrm{HHI}=1 \text { or else } \mathrm{HHI} \\
=0 \text {. }\end{array}$} \\
\hline & \multicolumn{4}{|c|}{ Firm Characteristics } \\
\hline IDR & \multicolumn{4}{|c|}{$\begin{array}{l}\text { Information disclosure ranking score, ranging from } 1 \text { (the lowest, } \mathrm{C}-\text { ) to } 7 \text { (the highest, } \\
\mathrm{A}++ \text { ). }\end{array}$} \\
\hline $\ln (\mathrm{BE})$ & \multicolumn{4}{|c|}{ Natural logarithm of book value of equity. } \\
\hline $\ln (\mathrm{NI})+$ & \multicolumn{4}{|c|}{ Natural logarithm of absolute value of net income. } \\
\hline$I_{<0}$ & \multicolumn{4}{|c|}{ It is 1 if the net income is negative, or else is 0.} \\
\hline SIZE & \multicolumn{4}{|c|}{ Natural logarithm of market capitalization. } \\
\hline LEV & \multicolumn{4}{|c|}{ The ratio of debt to book value of assets. } \\
\hline $\ln$ (Trading) & \multicolumn{4}{|c|}{ Natural logarithm of total number of trading days in a year. } \\
\hline $\ln ($ Inshd $)$ & \multicolumn{4}{|c|}{$\begin{array}{l}\text { Institutional ownership = natural logarithm of stock ownership of foreign institutions, } \\
\text { domestic funds, and securities companies. }\end{array}$} \\
\hline $\ln (1+$ Analyst $)$ & \multicolumn{4}{|c|}{ Natural logarithm of number of analysts providing earnings forecasts. } \\
\hline \multirow[t]{2}{*}{$\ln$ (Liquidity) } & \multicolumn{4}{|c|}{$\begin{array}{l}\text { Illiquidity ratio defined as natural logarithm of average daily absolute return divided } \\
\text { by dollar trading volume in millions of a year. }\end{array}$} \\
\hline & \multicolumn{4}{|c|}{ Agency-based measurements } \\
\hline SDS & \multicolumn{4}{|c|}{ Percentage of total outstanding shares owned by directors and supervisors. } \\
\hline SLS & \multicolumn{4}{|c|}{ Percentage of total outstanding shares owned by largest shareholder. } \\
\hline TFV & \multicolumn{4}{|c|}{ Times of seating to voting rights $=$ seating rights $\% /$ voting rights $\%$} \\
\hline TSE & \multicolumn{4}{|c|}{ It is 1 if the listed company and 0 is OTC firm. } \\
\hline \multicolumn{5}{|c|}{ Panel B: Measurements of information disclosure rankings based on five different dimensions [46] } \\
\hline Dimension & Item range & Total items & $\begin{array}{l}\text { Percentage of total } \\
\text { items represented }\end{array}$ & $\begin{array}{l}\text { Items with extra } \\
\text { rewards }\end{array}$ \\
\hline (1) Regulatory compliance & $1-12$ & 12 & $11 \%$ & None \\
\hline (2) Timeliness of information disclosure & $13-39$ & 27 & $23 \%$ & 9 items \\
\hline (3) Disclosure of financial forecast & $40-44$ & 5 & $4 \%$ & 5 items \\
\hline (4) Disclosure of annual report & $45-94$ & 50 & $44 \%$ & 4 items \\
\hline (5) Disclosure of firm website & $95-114$ & 20 & $18 \%$ & 20 items \\
\hline Total & & & $100 \%$ & 38 items \\
\hline
\end{tabular}

\subsection{Endogeneity Problem}

This section details the endogenous relationship discovered between company information disclosure rankings and mispricing. In addition to improving the degree of mispricing, information disclosure may improve the information disclosure score as a result of decreased mispricing. However, although this study considers factors that may be related to the degree of deviation of information disclosure from corporate value and controls them to mitigate the problem of endogeneity $[46,55,56]$, other endogenous links may exist. Therefore, this study uses a two-stage least squares method with instrumental variables (IVs) to address the endogeneity between information disclosure and mispricing [57-59].

In the selection of IVs, we adopt the method used by Cui et al. [60] and Gong and Ho [52,61] to consider changes in the first two periods of information disclosure (IDR $t_{t-1}$ and IDR $\mathrm{ID}_{t-2}$ ) and the 
median information disclosure in each industry ( $\left(\mathrm{IDR}_{\text {Industry }}\right)$ and control other possible corporate governance IVs. We also apply the method presented by Chung et al. [14] and use the following criteria: proportion of shares owned by domestic trst funds (\%DTF), family institutional investors (\%FI), family-controlled foundations ( $\% \mathrm{FF})$, and listed companies controlled by family directors (\%FL); board independence (ID_Rate); listed companies (TSE); and changes in chairman of the board (Chairman_C), CEO (CEO_C), CFO (CFO_C), spokesman (Spokesman_C), and audit (Audit_C). The first stage of the least squares method entails using the method proposed by Larcker and Rusticus [62] to regress all selected exogenous IVs. The second stage entails the execution of least squares regression using the information disclosure ranking (IDR) valuation (IDR 2 SLS) estimated in the first stage to identify any influence that helps to reduce the degree of mispricing. Equation (6) represents the first stage of the least squares method:

$$
\begin{aligned}
& \mathrm{IDR}_{i t}=\lambda_{0}+\lambda_{1} \mathrm{IDR}_{i, t-1} \\
& +\lambda_{2} \mathrm{IDR}_{i, t-2}+\lambda_{3} \mathrm{IDR}_{\text {Industry }, t}+\lambda_{4} \% \mathrm{DEF}_{i t} \\
& +\lambda_{5} \% \mathrm{FI}_{i t}+\lambda_{6} \% \mathrm{FF}_{i t}+\lambda_{7} \% \mathrm{FL}_{i t}+\lambda_{8} I_{-} \text {Rate }_{i t}+\lambda_{9} \text { Chairman_C } \mathrm{C}_{i t} \\
& +\lambda_{10} \mathrm{CEO}_{-} \mathrm{C}_{i t}+\lambda_{11} \mathrm{CFO} \mathrm{C}_{i t} \\
& +\lambda_{12} \text { Spokeman_C } i t+\lambda_{13} \text { Audit_C } C_{i t}+\lambda_{14} \mathrm{SIZE}_{i t}+\lambda_{15} \mathrm{LEV}_{i t} \\
& +\lambda_{16} \ln (\text { Trading })_{i t}+\lambda_{17} \ln (\text { Inshd })_{i t}+\lambda_{18} \ln (\text { Liquidity })_{i t} \\
& +\lambda_{19} \mathrm{SDS}_{i t}+\lambda_{20} \mathrm{SLS}_{i t}+\lambda_{21} \mathrm{TSV}_{i t}+\text { Time } \mathrm{FE}+\text { Industry } \mathrm{FE}+\varepsilon_{i t}
\end{aligned}
$$

\subsection{Summary Statistics}

As presented in panel A of Table 2, the IDRs of the sample firms are arranged from the lowest score $1(\mathrm{C}-)$ to the highest score $7(\mathrm{~A}++)$. The average value of IDR is 3.59 and the median is 3 . This indicates that the sample firms have lower than average IDRs. The mean and median of HHI are 0.16 and 0.11 , respectively, suggesting that industry product market competition is generally high in all sample firms. Panel B of Table 2 presents the distribution of sample corporations according to industry product market competition. Among the 30 industries, we discover that the electronics industry constitutes two-thirds of the sample because this is a major industry in Taiwan. However, some corporations are in oligopoly industries and are involved in the production of cement, food, electric cables, glass ceramics, paper, auto parts, other electronics, oil, gas, or electricity.

Table 2. Summary statistics.

\begin{tabular}{cccccc}
\hline \multicolumn{2}{l}{ Panel A: Summary statistics of all firms } & & & & \\
\hline & MEAN & STD & Q1 & MEDIAN & Q3 \\
\hline IDR & 3.59 & 1.18 & 3.00 & 3.00 & 5.00 \\
Mispricing1 & 0.00 & 0.43 & -0.27 & -0.08 & 0.18 \\
Mispricing2 & 0.00 & 0.79 & -0.46 & -0.03 & 0.42 \\
HHI & 0.16 & 0.17 & 0.08 & 0.11 & 0.18 \\
SIZE & 15.53 & 1.59 & 14.43 & 15.27 & 16.28 \\
LEV & 1.27 & 2.79 & 0.39 & 0.73 & 1.21 \\
$\ln$ (Trading) & 5.57 & 0.17 & 5.51 & 5.52 & 3.53 \\
$\ln$ (Inshd) & $2.91 \%$ & $5.77 \%$ & $0.00 \%$ & $0.30 \%$ & 2.20 \\
$\ln (1+$ Analyst) & 1.18 & 1.33 & 0.00 & 0.69 & $0.01 \%$ \\
$\ln$ (Liquidity) & $0.05 \%$ & $0.19 \%$ & $0.00 \%$ & $0.00 \%$ & 29.81 \\
SDS & 23.10 & 14.28 & 12.62 & 19.53 & 25.55 \\
SLS & 19.75 & 11.53 & 11.77 & 17.74 & 34.33 \\
TSV & 23.86 & 17.43 & 9.90 & 19.94 & \\
\hline
\end{tabular}


Table 2. Cont.

\begin{tabular}{|c|c|c|c|}
\hline \multicolumn{4}{|c|}{ Panel B: Summary statistics of all industries } \\
\hline Classification & Industry & Industrial concentration level & HHI \\
\hline 1 & Cement & Oligopoly & 0.42 \\
\hline 2 & Food & Oligopoly & 0.39 \\
\hline 3 & Plastics & General & 0.21 \\
\hline 4 & Textile & General & 0.20 \\
\hline 5 & Electric machinery & General & 0.15 \\
\hline 6 & Electric cables & Oligopoly & 0.32 \\
\hline 7 & Chemical industry & Competition & 0.08 \\
\hline 8 & Biotechnology and medical care & Competition & 0.06 \\
\hline 9 & Glass ceramic & Oligopoly & 0.51 \\
\hline 10 & Paper & Oligopoly & 0.28 \\
\hline 11 & Steel & General & 0.21 \\
\hline 12 & Rubber & Oligopoly & 0.25 \\
\hline 13 & Auto & Oligopoly & 0.26 \\
\hline 14 & Semiconductor & Competition & 0.10 \\
\hline 15 & Computer peripherals & Competition & 0.11 \\
\hline 16 & Photoelectric & Competition & 0.12 \\
\hline 17 & $\begin{array}{c}\text { Communications network } \\
\text { operator }\end{array}$ & Competition & 0.11 \\
\hline 18 & Electronic components & Competition & 0.03 \\
\hline 19 & Electronic access & Competition & 0.12 \\
\hline 20 & Information services & Competition & 0.09 \\
\hline 21 & Other electronics & Oligopoly & 0.74 \\
\hline 22 & Building material and construction & Competition & 0.04 \\
\hline 23 & Shipping & General & 0.16 \\
\hline 24 & Sightseeing & General & 0.13 \\
\hline 25 & Finance and insurance & General & 0.15 \\
\hline 26 & Trade department & General & 0.20 \\
\hline 27 & Securities & General & 0.15 \\
\hline 28 & Culture & General & 0.22 \\
\hline 29 & Oil, gas and electricity & Oligopoly & 0.85 \\
\hline 30 & Other & General & 0.13 \\
\hline
\end{tabular}

Note: This table reports descriptive statistics of explanatory variables, industry characteristics, firm characteristics, and agency-based proxies for sample firms. The definitions of the variables are shown in detail in Table 1.

To identify potential multicollinearity among the explanatory variables, we examine the correlations and variance inflation factor among all independent variables. Table 3 indicates that there are no multicollinearity problems.

Table 3. Correlation matrix.

\begin{tabular}{|c|c|c|c|c|c|c|c|c|c|c|c|c|}
\hline & VIF & IDR & HHI & SIZE & LEV & $\ln$ (Trading) & $\ln$ (Inshd) & $\begin{array}{c}\ln (1+ \\
\text { Analyst) }\end{array}$ & $\ln$ (Liquidity) & SDS & SLS & TSV \\
\hline IDR & 1.13 & 1.00 & & & & & & & & & & \\
\hline HHI & 1.04 & -0.01 & 1.00 & & & & & & & & & \\
\hline LEV & 1.45 & 0.16 & -0.02 & 0.49 & 1.00 & & & & & & & \\
\hline $\ln$ (Trading) & 1.22 & 0.05 & -0.05 & 0.19 & 0.03 & 1.00 & & & & & & \\
\hline $\ln ($ Inshd $)$ & 1.29 & 0.22 & 0.06 & 0.42 & 0.30 & 0.05 & 1.00 & & & & & \\
\hline SDS & 1.53 & -0.01 & 0.11 & -0.11 & 0.01 & -0.16 & 0.05 & -0.13 & -0.04 & 1.00 & & \\
\hline SLS & 1.56 & -0.03 & 0.00 & -0.02 & 0.04 & -0.08 & 0.00 & -0.13 & -0.01 & -0.17 & 1.00 & \\
\hline TSV & 1.83 & -0.11 & 0.10 & -0.13 & 0.01 & -0.13 & -0.08 & -0.23 & -0.03 & 0.40 & 0.45 & 1.00 \\
\hline
\end{tabular}

Note: This table reports the Pearson correlation coefficients and Variance Inflation Factor (VIF) between independent variables. The definitions of the variables are shown in detail in Table 1. The boldfaced numbers denote statistical significance below $10 \%$. 


\section{Empirical Results}

\subsection{Effect of IDR on Mispricing}

In this study, we refer to the methods presented by Berger and Ofek [54], Rhodes-Kropf et al. [53], and Chu et al. [40] to estimate the degree of mispricing of the sample companies. In Table 4, empirical results reveal the effect of IDR on the degree of mispricing; the coefficient is -0.008 ( $\mathrm{t}$-statistic $=-2.64$ ) in the Mispricing1 regression and -0.032 (t-statistic $=-5.04)$ in the Mispricing 2 regression. The IDR score is significantly representative because the different methods for estimating the degree of mispricing all maintain a significance level of less than $1 \%$, even after we control for both the year and industry fixed effects. Therefore, we standardize annual IDRs by using the following formula: (original IDR-average annual information disclosure)/standard deviation of IDRs. The standard deviation of IDRs is calculated from the standardized information disclosure score. This result is consistent with those of previous analyses [46]. The regression analysis results verify that IDRs effectively reduce the degree of mispricing, which supports the findings of Lee and Lee [45] and Chu et al. [40]. The higher quality is the disclosed information, the better investors can evaluate firms, and hence the stock price is closer to the firm's true fundamentals. On the other hand, if the information disclosed to investors is inaccurate, incomplete, late or even fraudulent, the market valuation will hardly be accurate hence the stock price is likely to deviate much form the firm's true fundamental.

Table 4. Effect of IDR on mispricing.

\begin{tabular}{lll}
\hline \multicolumn{1}{c}{ Dependent Variable } & \multicolumn{1}{c}{ Mispricing1 } & \multicolumn{1}{c}{ Mispricing2 } \\
\hline Intercept & $1.713^{* * *}$ & $1.539^{* * *}$ \\
& $(14.37)$ & $(6.18)$ \\
\hline IDR & $-0.008^{* * *}$ & $-0.032^{* * *}$ \\
& $(-2.64)$ & $(-5.04)$ \\
\hline SIZE & $-0.121^{* * * *}$ & $-0.105^{* * *}$ \\
LEV & $(-37.23)$ & $(-15.57)$ \\
& $0.073^{* * *}$ & $0.036^{* * *}$ \\
$\ln$ (Trading) & $(38.98)$ & $(9.31)$ \\
& -0.005 & 0.031 \\
$\ln ($ Inshd) & $(-0.23)$ & $(0.75)$ \\
& $0.183^{* * *}$ & $1.373^{* * *}$ \\
$\ln (1+$ Analyst $)$ & $(2.93)$ & $(10.56)$ \\
& $0.114^{* * *}$ & $0.071^{* * *}$ \\
$\ln ($ Liquidity) & $(34.24)$ & $(10.27)$ \\
& $-13.617^{* * *}$ & $-14.129^{* * *}$ \\
SDS & $(-6.78)$ & $(-3.37)$ \\
& $0.002^{* * *}$ & 0.001 \\
SLS & $(6.59)$ & $(1.39)$ \\
TSV & $0.002^{* * *}$ & $0.006^{* * *}$ \\
& $(6.45)$ & $(7.90)$ \\
\hline Year FE & $-0.001^{* * *}$ & 0.000 \\
Industry FE & $(-4.83)$ & $(-0.57)$ \\
\hline Adj R & YES & YES \\
N & YES & YES \\
\hline
\end{tabular}

Note: This table reports the impact of IDR on mispricing. All models are based on Equation (4). The definitions of the variables are shown in detail in Table 1 . The t-statistics are based on standard errors clustered by industry and year and reported in the parenthesis. ${ }^{*}, * *, * * *$ denote statistical significance at $10 \%, 5 \%$, and $1 \%$, respectively. 


\subsection{Effect of IDR on Mispricing in Industries with Different Levels of Product Market Competition}

Table 5 presents the results of investigating the effect of IDR on the degree of mispricing in industries with different levels of market competition (HHI). We conduct a test using the method presented by Giroud and Mueller [50]. The empirical results indicate a $(3 \times 1)$ vector interaction between IDR and HHI, and the HHI can be divided into three distinct groups: high HHI (33\%), median HHI (34\%), and low HHI (33\%). In Mispricing1, the coefficient for the interaction between IDR and $\mathrm{HHI}$ (high) is -0.006 ( $\mathrm{t}$-statistic $=-0.83$ ), that for the interaction between IDR and HHI (median) is 0.006 (t-statistic $=1.38$ ), and that for the interaction between IDR and HHI (low) is -0.019 (t-statistic $=-4.69)$. The Mispricing2 regression indicates that the $(3 \times 1)$ vector coefficient for the interaction between IDR and HHI (high) is -0.025 ( $\mathrm{t}$-statistic $=-1.59$ ), that for the interaction between IDR and $\mathrm{HHI}$ (median) is -0.010 (t-statistic $=-1.04$ ), and that for the interaction between IDR and HHI (low) is -0.049 ( $\mathrm{t}$-statistic $=-5.75$ ). All interactions between IDR and HHI (high or median) are nonsignificant, and the interaction between IDR and HHI (low) is significantly negative. IDRs do not exhibit an influence on mispricing in oligopoly industries. However, regarding the interaction between IDR and the lowest HHI (competitive industries), financial risk and default probability are higher for these industries compared with others; therefore, investors should consider information transparency prior to investing. If a firm has higher information disclosure quality, then investors will have more confidence when investing in the firm, which reduces mispricing.

Table 5. The impact of IDR on mispricing under different industry product market competition level.

\begin{tabular}{|c|c|c|}
\hline Dependent Variable & Mispricing1 & Mispricing2 \\
\hline Intercept & $\begin{array}{l}1.801^{* * *} \\
(15.00)\end{array}$ & $\begin{array}{l}1.650^{* * *} \\
(6.58)\end{array}$ \\
\hline IDR*HHI(high) & $\begin{array}{l}-0.006 \\
(-0.83)\end{array}$ & $\begin{array}{l}-0.025 \\
(-1.59)\end{array}$ \\
\hline IDR*HHI(median) & $\begin{array}{l}0.006 \\
(1.38)\end{array}$ & $\begin{array}{l}-0.010 \\
(-1.04)\end{array}$ \\
\hline IDR*HHI(low) & $\begin{array}{l}-0.019^{* * *} \\
(-4.69)\end{array}$ & $\begin{array}{l}-0.049^{* * *} \\
(-5.75)\end{array}$ \\
\hline HHI(median) & $\begin{array}{l}-0.137^{* * *} \\
(-5.56)\end{array}$ & $\begin{array}{l}-0.177^{* * *} \\
(-3.42)\end{array}$ \\
\hline HHI(high) & $\begin{array}{l}-0.104^{* * *} \\
(-2.71)\end{array}$ & $\begin{array}{l}-0.168^{* *} \\
(-2.09)\end{array}$ \\
\hline SIZE & $\begin{array}{l}-0.120^{* * *} \\
(-37.21)\end{array}$ & $\begin{array}{l}-0.105^{* * *} \\
(-15.56)\end{array}$ \\
\hline LEV & $\begin{array}{l}0.073^{* * *} \\
(38.91)\end{array}$ & $\begin{array}{l}0.036^{* * *} \\
(9.25)\end{array}$ \\
\hline $\ln$ (Trading) & $\begin{array}{l}-0.007 \\
(-0.33)\end{array}$ & $\begin{array}{l}0.028 \\
(0.68)\end{array}$ \\
\hline $\ln ($ Inshd $)$ & $\begin{array}{l}0.195^{* * *} \\
(3.13)\end{array}$ & $\begin{array}{l}1.388^{* * *} \\
(10.67)\end{array}$ \\
\hline $\ln (1+$ Analyst $)$ & $\begin{array}{l}0.113^{* * *} \\
(33.87)\end{array}$ & $\begin{array}{l}0.070 * * * \\
(10.08)\end{array}$ \\
\hline $\ln$ (Liquidity) & $\begin{array}{l}-13.881 \\
(-6.92)\end{array}$ & $\begin{array}{l}-14.414^{* * *} \\
(-3.44)\end{array}$ \\
\hline SDS & $\begin{array}{l}0.002^{* * *} \\
(6.54)\end{array}$ & $\begin{array}{l}0.001 \\
(1.36)\end{array}$ \\
\hline SLS & $\begin{array}{l}0.002 \text { *** } \\
(6.50)\end{array}$ & $\begin{array}{l}0.006^{* * *} \\
(7.93)\end{array}$ \\
\hline TSV & $\begin{array}{l}-0.001 \\
(-4.85)\end{array}$ & $\begin{array}{l}0.000 \\
(-0.55)\end{array}$ \\
\hline Year FE & YES & YES \\
\hline Industry FE & YES & YES \\
\hline $\begin{array}{l}\text { Adj } R^{2} \\
N\end{array}$ & $\begin{array}{l}0.43 \\
10,686\end{array}$ & $\begin{array}{l}0.18 \\
10,686\end{array}$ \\
\hline
\end{tabular}

Note: This table reports the impact of information disclosure ranking on mispricing under different industry product market competition levels. All models are based on Equation (5). The definitions of the variables are shown in detail in Table 1 . The t-statistics are based on standard errors clustered by industry and year and reported in the parenthesis. ${ }^{*}, * *, * *$ denote statistical significance at $10 \%, 5 \%$, and $1 \%$, respectively. 


\subsection{Tests of the Endogeneity Effect}

Table 6 presents the results obtained from the use of the two-stage least square method to solve the problem of endogeneity. We use the method proposed by Larcker and Rusticus [62] to regress all selected exogenous IVs in the first stage of the least squares regression to estimate IDRs. The IDRs estimated in first stage of the least squares regressions are then used to evaluate the effect of IDR on mispricing. Using the methods presented by Chung et al. [14] and Cui et al. [60], we regress IVs on IDRs in the first stage of the least squares regression. We discover that the coefficient of the estimated IDRs in the second-stage regression on Mispricing1 is -0.008 ( $\mathrm{t}$-statistic $=-1.76$ ). In the Mispricing2 regression, the coefficient of the estimated IDRs is -0.048 ( $\mathrm{t}$-statistic $=-5.16)$. The empirical results indicate that the IDRs estimated using IVs significantly reduce mispricing. Moreover, we use this method to solve the problem of endogeneity. Another analysis confirms the robustness of this result. According to the method presented by Gong and Ho [61], we use the Generalized Method of Moments (GMM) approach to solve the problem of endogeneity, and the consistent results support our findings.

Table 6. Two-stage least squares (2SLS) regression analysis for the relationship between mispricing and IDR.

\begin{tabular}{|c|c|c|c|}
\hline Dependent Variable & First Stage: IDR & $\begin{array}{l}\text { Second Stage: } \\
\text { Mispricing1 }\end{array}$ & $\begin{array}{l}\text { Second Stage: } \\
\text { Mispricing2 }\end{array}$ \\
\hline Intercept & $\begin{array}{l}-1.976^{* * *} \\
(-5.13)\end{array}$ & $\begin{array}{l}1.569^{* * *} \\
(12.17)\end{array}$ & $\begin{array}{l}1.434^{* * *} \\
(5.26)\end{array}$ \\
\hline $\mathrm{IDR}_{t-1}$ & $\begin{array}{l}0.635^{* * *} \\
(69.73)\end{array}$ & & \\
\hline $\mathrm{IDR}_{t-2}$ & $\begin{array}{l}0.119^{* * *} \\
(13.41)\end{array}$ & & \\
\hline $\mathrm{IDR}_{\text {Industry }}$ & $\begin{array}{l}0.727^{* * * *} \\
(12.74)\end{array}$ & & \\
\hline$\%$ DTF & $\begin{array}{l}0.000 \\
(-0.11)\end{array}$ & & \\
\hline$\% \mathrm{FI}$ & $\begin{array}{l}0.001 \\
(1.00)\end{array}$ & & \\
\hline$\% \mathrm{FF}$ & $\begin{array}{l}0.001 \\
(0.61)\end{array}$ & & \\
\hline$\% \mathrm{FL}$ & $\begin{array}{l}0.002 \\
(1.45)\end{array}$ & & \\
\hline ID_Rate & $\begin{array}{l}0.080^{*} \\
(1.87)\end{array}$ & & \\
\hline Chairman_C & $\begin{array}{l}-0.005 \\
(-0.17)\end{array}$ & & \\
\hline CEO_C & $\begin{array}{l}0.014 \\
(0.63)\end{array}$ & & \\
\hline CFO_C & $\begin{array}{l}-0.001 \\
(-0.03)\end{array}$ & & \\
\hline Spokeman_C & $\begin{array}{l}0.004 \\
(0.19)\end{array}$ & & \\
\hline Aduit_C & $\begin{array}{l}-0.040 * * \\
(-2.21)\end{array}$ & & \\
\hline TSE & $\begin{array}{l}-0.103 \text { *** } \\
(-5.25)\end{array}$ & & \\
\hline
\end{tabular}


Table 6. Cont.

\begin{tabular}{|c|c|c|c|}
\hline Dependent Variable & First Stage: IDR & $\begin{array}{l}\text { Second Stage: } \\
\text { Mispricing1 }\end{array}$ & $\begin{array}{l}\text { Second Stage: } \\
\text { Mispricing2 }\end{array}$ \\
\hline $\mathrm{IDR}_{2 S L S}$ & & $\begin{array}{l}-0.008 * \\
(-1.76)\end{array}$ & $\begin{array}{l}-0.048^{* * *} \\
(-5.16)\end{array}$ \\
\hline SIZE & $\begin{array}{l}0.056^{* * *} \\
(6.05)\end{array}$ & $\begin{array}{l}-0.120 * * * \\
(-33.79)\end{array}$ & $\begin{array}{l}-0.105^{* * *} \\
(-13.97)\end{array}$ \\
\hline LEV & $\begin{array}{l}-0.010 \text { ** } \\
(-2.21)\end{array}$ & $\begin{array}{l}0.075^{* * *} \\
(36.72)\end{array}$ & $\begin{array}{l}0.042^{* * *} \\
(9.65)\end{array}$ \\
\hline $\ln$ (Trading) & $\begin{array}{l}-0.095 * \\
(-1.92)\end{array}$ & $\begin{array}{l}0.018 \\
(0.85)\end{array}$ & $\begin{array}{l}0.056 \\
(1.23)\end{array}$ \\
\hline $\ln ($ Inshd $)$ & $\begin{array}{l}0.279 * \\
(1.75)\end{array}$ & $\begin{array}{l}0.256^{* * *} \\
(3.78)\end{array}$ & $\begin{array}{l}1.507^{* * *} \\
(10.52)\end{array}$ \\
\hline $\ln (1+$ Analyst $)$ & $\begin{array}{l}0.024^{* * *} \\
(2.83)\end{array}$ & $\begin{array}{l}0.107^{* * *} \\
(28.88)\end{array}$ & $\begin{array}{l}0.062^{* * *} \\
(7.96)\end{array}$ \\
\hline $\ln$ (Liquidity) & $\begin{array}{l}-3.517 \\
(-0.62)\end{array}$ & $\begin{array}{l}-16.966^{* * *} \\
(-6.90)\end{array}$ & $\begin{array}{l}-17.544^{* * *} \\
(-3.37)\end{array}$ \\
\hline SDS & $\begin{array}{l}0.000 \\
(0.39)\end{array}$ & $\begin{array}{l}0.002^{* * * *} \\
(7.42)\end{array}$ & $\begin{array}{l}0.002^{* * * *} \\
(2.84)\end{array}$ \\
\hline SLS & $\begin{array}{l}0.000 \\
(0.20)\end{array}$ & $\begin{array}{l}0.003^{* * *} \\
(6.74)\end{array}$ & $\begin{array}{l}0.007^{* * *} \\
(8.09)\end{array}$ \\
\hline TSV & $\begin{array}{l}-0.001 \\
(-1.57)\end{array}$ & $\begin{array}{l}-0.001 * * * \\
(-5.22)\end{array}$ & $\begin{array}{l}-0.001 \\
(-1.26)\end{array}$ \\
\hline Year FE & YES & YES & YES \\
\hline Industry FE & YES & YES & YES \\
\hline $\begin{array}{l}\text { Adj } R^{2} \\
N\end{array}$ & $\begin{array}{l}0.63 \\
9071\end{array}$ & $\begin{array}{l}0.42 \\
9071\end{array}$ & $\begin{array}{l}0.17 \\
9071\end{array}$ \\
\hline
\end{tabular}

Note: The table reports the two-stage least squares (2SLS) regression analysis results for examining whether information ranking explains mispricing. All models are based on Equation (6). The definitions of the variables are shown in detail in Table 1 and Section 3. The t-statistics are based on standard errors clustered by industry and year and reported in the parenthesis. ${ }^{*}, * *, * *$ denote statistical significance at $10 \%, 5 \%$, and $1 \%$, respectively.

\section{Conclusions}

After Enron acquired a substantial debt risk, WorldCom, Tyco, and Merck were also involved in accounting scandals that not only caused an increase in the stock market margin but also reduced investor confidence. This study uses the IDR indicators established by the SFI to divide the IDR score into seven points. During the sample period of 2005 to 2014, we obtain the data of 10,686 listed companies. This study reveals that the information disclosure work evaluation system promoted by the SFI and IDR significantly affects the quality and amount of information disclosed by the evaluated enterprises. Moreover, the empirical results of this study reveal that the transparency indicator of information disclosure helps to reduce the degree of mispricing. Considering the disadvantages of low liquidity and high capital costs that may accompany low information transparency, companies focusing on information disclosure will eventually reduce their degree of mispricing.

From the perspective of the external environment, the size and transparency of the monopolistic industry will help reduce the mispricing of enterprise value. Additionally, this study provides further evidence that industry product market competition is separated into three groups. Negative relationships between IDR and mispricing are only observed in competitive industries because of their relatively high financial risk and default probability, which prompts investors to consider information transparency. If a firm increases their information transparency, investors will have more interest and confidence in investing in the firm, leading to reduced mispricing. This evidence supports the notion that IDRs effectively reduce mispricing in competitive industries. Policies related to the promotion of information disclosure outside of the SFI can also be affirmed using our results. Moreover, information disclosure ranking firms are found to be more ethical, trustworthy, and honest, and managers are 
encouraged to undertake actions that boost long-term sustainable development, thus resulting in less mispricing.

Author Contributions: Writing: B.W. and H.-Y.H.; Providing idea and data: K.-C.H. and I-M.J.; Revising and editing: S.X.

Funding: The authors were funded by the first-class discipline construction fund of the Zhongnan University of Economics and Law-the corporate finance team, the project of social science research base of Fujian China (grant no.FJ2018JDZ014), and NSFC number (71602151, 71771217, 71801226, 71803196).

Acknowledgments: This manuscript was edited by Wallace Academic Editing.

Conflicts of Interest: The authors declare no conflict of interest.

\section{References}

1. Jensen, M.C.; Meckling, W.H. Theory of the firm: Managerial behavior, agency costs and ownership structure. J. Financ. Econ. 1976, 3, 305-360. [CrossRef]

2. Fama, E.F. Agency problems and the theory of the firm. J. Political Econ. 1980, 88, 288-307. [CrossRef]

3. Fama, E.F.; Jensen, M.C. Separation of ownership and control. J. Law Econ. 1983, 26, 301-325. [CrossRef]

4. Bushman, R.M.; Smith, A.J. Financial Accounting Information and Corporate Governance. J. Account. Econ. 2001, 32, 237-333. [CrossRef]

5. Healy, P.M.; Palepu, K.G. Information asymmetry, corporate disclosure, and the capital markets: A review of the empirical disclosure literature. J. Account. Econ. 2001, 31, 405-440. [CrossRef]

6. Glosten, L.R.; Milgrom, P.R. Bid, ask, and transaction prices in a specialist market with heterogeneously informed traders. J. Financ. Econ. 1985, 14, 71-100. [CrossRef]

7. Diamond, D.W.; Verrecchia, R.E. Disclosure, liquidity, and the cost of capital. J. Financ. 1991, 46, 1325-1359. [CrossRef]

8. Botosan, C.A. Disclosure level and the cost of equity capital. Account. Rev. 1997, 72, 323-349.

9. Healy, P.M.; Hutton, A.P.; Palepu, K.G. Stock performance and intermediation changes surrounding sustained increases in disclosure. Contemp. Account. Res. 1999, 16, 485-520. [CrossRef]

10. Francis, J.; Nanda, D.; Olsson, P. Voluntary disclosure, earnings quality, and cost of capital. J. Account. Res. 2008, 46, 53-99. [CrossRef]

11. Gao, P. Disclosure quality, cost of capital, and investor welfare. Account. Rev. 2010, 85, 1-29. [CrossRef]

12. Hughes, J.S.; Liu, J.; Liu, J. Information asymmetry, diversification, and cost of capital. Account. Rev. 2007, 82, 705-729. [CrossRef]

13. Lambert, R.; Leuz, C.; Verrecchia, R.E. Accounting information, disclosure, and the cost of capital. J. Account. Res. 2007, 45, 385-420. [CrossRef]

14. Chung, H.; Judge, W.Q.; Li, Y.H. Voluntary disclosure, excess executive compensation, and firm value. J. Corp. Financ. 2015, 32, 64-91. [CrossRef]

15. Merton, R.C. A simple model of capital market equilibrium with incomplete information. J. Financ. 1987, 42, 483-510. [CrossRef]

16. Welker, M. Disclosure policy, information asymmetry, and liquidity in equity markets. Contemp. Account. Res. 1995, 11, 801-827. [CrossRef]

17. Leuz, C.; Verrecchia, R.E. The economic consequences of increased disclosure. J. Account. Res. 2000, 38, 91-124. [CrossRef]

18. Heflin, F.; Subramanyam, K.R.; Zhang, Y. Regulation FD and the financial information environment: Early evidence. Account. Rev. 2003, 78, 1-38. [CrossRef]

19. Klapper, L.F.; Love, I. Corporate governance, investor protection, and performance in emerging markets. J. Corp. Financ. 2004, 10, 703-728. [CrossRef]

20. Bai, C.E.; Liu, Q.; Lu, J.; Song, F.M.; Zhang, J. Corporate governance and market valuation in China. J. Comp. Econ. 2004, 32, 599-616. [CrossRef]

21. Black, B.S.; Inessa, L.; Rachinsky, A. Corporate governance indices and firms' market values: Time series evidence from Russia. Emerg. Mark. Rev. 2006, 7, 361-379. [CrossRef]

22. Braga-Alves, M.V.; Shastri, K. Corporate governance, valuation, and performance: Evidence from a voluntary market reform in Brazil. Financ. Manag. 2011, 40, 139-157. [CrossRef] 
23. Ho, K.C.; Pan, L.H.; Lin, C.T.; Lee, S.C. Information disclosure, product market competition, and firm value: Evidence from Taiwan. Soc. Sci. Electron. Publ. 2016. [CrossRef]

24. Elliott, R.K.; Jacobson, P.D. Costs and benefits of business information disclosure. Account. Horiz. 1994, 8 , 80-96.

25. Bloomfield, R.; Fischer, P.E. Disagreement and the cost of capital. J. Account. Res. 2011, 49, 41-68. [CrossRef]

26. Baker, M.; Stein, J.; Wurgler, J. When does the market matter? Stock prices and investment of equity-dependent firms. Q. J. Econ. 2003, 118, 969-1005. [CrossRef]

27. Stambaugh, R.F.; Yuan, Y. Mispricing factors. Rev. Financ. Stud. 2017, 30, 1270-1315. [CrossRef]

28. Sloan, R.G. Do stock prices fully reflect information in accruals and cash flows about future earnings? Account. Rev. 1996, 71, 289-315.

29. Ma, J.Z.; Deng, X.; Ho, K.C.; Tsai, S.B. Regime-switching determinants for spreads of emerging markets sovereign credit default swaps. Sustainability 2018, 10, 2730. [CrossRef]

30. Beretta, S.; Bozzolan, S. A framework for the analysis of firm risk communication. Int. J. Account. 2004, 39, 265-288. [CrossRef]

31. Beretta, S.; Bozzolan, S. Quality versus Quantity: The case of forward-looking disclosure. J. Account. Audit. Financ. 2008, 23, 333-375. [CrossRef]

32. Gelb, D.S.; Strawser, J.A. Corporate social responsibility and financial disclosure: An alternative explanation for increased disclosure. J. Bus. Ethics 2001, 33, 1-13. [CrossRef]

33. Chih, H.L.; Shen, C.H.; Kang, F.C. Corporate social responsibility, investor protection, and earnings management: Some international evidence. J. Bus. Ethics 2007, 79, 179-198. [CrossRef]

34. Choi, T.H.; Pae, J. Business ethics and financial reporting quality: Evidence from Korea. J. Bus. Ethics 2011, 103, 403-427. [CrossRef]

35. Murata, K. Analyzing environmental continuous improvement for sustainable supply chain management: Focusing on its performance and information disclosure. Sustainability 2016, 8, 1256. [CrossRef]

36. Manes-Rossi, F.; Tiron-Tudor, A.; Nicolò, G.; Zanellato, G. Ensuring more sustainable reporting in Europe using non-financial disclosure-De Facto and De Jure evidence. Sustainability 2018, 10, 1162. [CrossRef]

37. Li, M.; Tian, A.; Li, S.; Qi, X. Evaluating the quality of enterprise environmental accounting information disclosure. Sustainability 2018, 10, 2136. [CrossRef]

38. Bae, S.M.; Masud, A.K.; Kim, J.D. A cross-country investigation of corporate governance and corporate sustainability disclosure: A signaling theory perspective. Sustainability 2018, 10, 2611. [CrossRef]

39. Tang, Y.; Miao, X.; Zang, H.; Gao, Y. Information disclosure on hazards from industrial water pollution incidents: Latent resistance and countermeasures in China. Sustainability 2018, 10, 1475. [CrossRef]

40. Chu, C.C.; Ho, K.C.; Jiang, I.M.; Lo, C.C.; Karathanasopoulos, A. Information disclosure and transparency ranking system and firms' value deviation: Evidence from Taiwan. Rev. Quant. Financ. Account. 2018, 1-27. [CrossRef]

41. Hail, L. The impact of voluntary corporate disclosure on the ex-ante cost of capital for Swiss firms. Eur. Account. Rev. 2002, 11, 741-773. [CrossRef]

42. Drake, M.S.; Myers, J.N.; Myers, L.A. Disclosure quality and the mispricing of accruals and cash flow. J. Account. Audit. Financ. 2009, 24, 357-384. [CrossRef]

43. Jiao, Y. Corporate disclosure, market valuation, and firm performance. Financ. Manag. 2011, 40, 647-676. [CrossRef]

44. Kobayashi, T.; Iwanaga, Y.; Kudoh, H. Japanese patent index and stock performance. J. Financ. Perspect. 2014, 2, 151-162.

45. Lee, H.L.; Lee, H. Effect of information disclosure and transparency ranking system on mispricing of accruals of Taiwanese firms. Rev. Quant. Financ. Account. 2015, 44, 445-471. [CrossRef]

46. Pan, L.H.; Lin, C.T.; Lee, S.C.; Ho, K.C. Information ratings and capital structure. J. Corp. Financ. 2015, 31, 17-32. [CrossRef]

47. Bens, D. The determinants of the amount of information disclosed about corporate restructurings. J. Account. Res. 2002, 40, 1-20. [CrossRef]

48. Healy, P.; Palepu, K.G. The effect of firms' financial disclosure strategies on stock prices. Account. Horiz. 1993, 7,1 .

49. Giroud, X.; Mueller, H.M. Does corporate governance matter in competitive industries? J. Financ. Econ. 2010, 95, 312-331. [CrossRef] 
50. Giroud, X.; Mueller, H.M. Corporate governance, product market competition, and equity prices. J. Financ. 2011, 66, 563-600. [CrossRef]

51. Hou, K.; Robinson, D.T. Industry concentration and average stock returns. J. Financ. 2006, 61, 1927-1956. [CrossRef]

52. Gong, Y.; Ho, K.C. Does corporate social responsibility matter for corporate stability? Evidence from China. Qual. Quant. 2018, 52, 2291-2319. [CrossRef]

53. Rhodes-Kropf, M.; Robinson, D.T.; Viswanathan, S. Valuation waves and merger activity: The empirical evidence. J. Financ. Econ. 2005, 77, 561-603. [CrossRef]

54. Berger, P.G.; Ofek, E. Diversification's effect on firm value. J. Financ. Econ. 1995, 37, 39-65. [CrossRef]

55. Brick, I.E.; Palmon, O.; Wald, J.K. CEO compensation, director compensation, and firm performance: Evidence of cronyism. J. Corp. Financ. 2006, 12, 403-423. [CrossRef]

56. Dittmar, A.; Mahrt-Smith, J. Corporate governance and the value of cash holdings. J. Financ. Econ. 2007, 83, 599-634. [CrossRef]

57. Beedles, W.L. A micro-econometric investigation of multi-objective firms. J. Financ. 1977, 32, 1217-1233. [CrossRef]

58. Hauner, D.; Prati, A.; Bircan, C. The interest group theory of financial development: Evidence from regulation. J. Bank. Financ. 2013, 37, 895-906. [CrossRef]

59. Boone, A.; White, J.T. The effect of institutional ownership on firm transparency and information production. J. Financ. Econ. 2015, 117, 508-533. [CrossRef]

60. Cui, J.; Jo, H.; Na, H. Does corporate social responsibility affect information asymmetry? J. Bus. Ethics 2018, 3, 549-575. [CrossRef]

61. Gong, Y.; Ho, K.C. Corporate social responsibility and managerial short-termism. Asia-Pac. J. Account. Econ. 2018, 25, 1-27. [CrossRef]

62. Larcker, D.F.; Rusticus, T.O. On the use of instrumental variables in accounting research. J. Account. Econ. 2010, 49, 186-205. [CrossRef]

(C) 2019 by the authors. Licensee MDPI, Basel, Switzerland. This article is an open access article distributed under the terms and conditions of the Creative Commons Attribution (CC BY) license (http:/ / creativecommons.org/licenses/by/4.0/). 